\title{
The Effect Of The Relationships Between Affiliated Firms On Direction Of Income Shifting Within Business Groups
}

\author{
Kyung Jin Park, Myongji University, Korea \\ Joohyun Lim, Yonsei University, Korea \\ Ki Young Kim, Myongji University, Korea
}

\begin{abstract}
In this study, we examined how income shifting performs among affiliates in a business group to maximize the benefits of the entire business group in terms of minimizing the tax burden, with a particular focus on the direction of income shifting between affiliates within the business group. We find that tax-related decision-making for the entire business group is affected by the relationships between the affiliated firms, that is, the ownership structure of the whole business group. To analyze the ownership structure, we use centrality measures in a social network analysis. The results show that affiliates with the higher outdegree-centrality; that is, firms investing more shareholdings in other affiliates have a tendency to perform more income shifting. On the other hand, the affiliates with high indegree-centrality, that is, firms which are owned by other affiliates, were revealed to be given the income shifting from other affiliated firms to minimize the tax burden of the entire business group.
\end{abstract}

Keywords: Affiliated Firms; Income Shifting; Business Group

\section{INTRODUCTION}

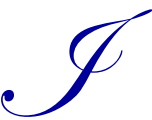

ncome shifting through internal transactions between affiliated firms in Korean business groups ${ }^{1}$ are conducted for various reasons. The first incentive is to maximize the private profit of the controlling shareholders. In the case of business groups in South Korea, it is possible to control the entire business group with minimal capital because the controlling shareholders and their relatives (the controlling family, hereinafter referred to as the "controlling shareholders") control the cashflow rights through pyramidal shareholdings or cross-shareholdings between affiliated firms within the business group. Therefore, the controlling shareholders have considerable incentive to maximize profits for the benefit of the entire business group, rather than seeing the company as an individual enterprise for their own private benefit. This attitude can reduce the benefits to minority shareholders of an individual enterprise. In many instances, controlling shareholders make affiliated firms with their larger shares purchase the goods and services at a lower price from the affiliated firms with fewer shares or sell them at a higher price to the affiliated firms with smaller shares using their control. Controlling shareholders can also conduct the internal transactions between those affiliated firms, such as borrowing at lower interest rates than those available in the market or providing loans at higher interest rates. Through these internal transactions, distribution of wealth may occur. This behavior, which infringes on the interests of minority shareholders, has been called "tunneling" (Johnson, La Porta, Lopez-de-Silanes, \& Shleifer, 2000).

Friedman, Johnson, and Mitton (2003) and Riyanto and Toolsema (2008) identified the phenomenon known as "propping," in which controlling shareholders sacrifice their own interests to support floundering affiliated firms. Propping, which is the opposite of tunneling, enables good management of the entire group. It entails support from controlling shareholders to affiliated firms in the form of private resources. Unlike tunneling, the resource input by controlling shareholders may be of interest to minority shareholders. In addition, aid may also be given

${ }^{1}$ Refer to Appendix 1. 
between affiliated firms, separate from the private interests of controlling shareholders. Internal transactions within the same business group can assist ailing firms greatly, which helps the entire group.

Because internal markets can be more efficient than external markets, internal transactions between affiliated firms are often conducted to improve the efficiency of the entire business group. Because internal financing is more advantageous to purchasing costs than external financing, recipient firms can use the resulting funds to invest or expand a new business.

Income shifting through internal transactions can also relieve the tax burden and maximize the interests of the business group. Jung, Kim, and Kim (2009) revealed that in some business groups, gains are transferred to affiliated firms with smaller tax burdens to minimize the tax burden of the entire group. Once the cash reserve drain of the entire business group has been minimized due to alleviation of the tax burden, efficiency will increase. In addition, income shifting increases as the equity rates of controlling shareholders increase (i.e., tunneling behavior). In this scenario, controlling shareholders shift their income to maximize their own interests (Jung, Kim, \& Kim, 2009). Income shifting is conducted from affiliated firms with a large tax burden to those with a small tax burden. Here, firms with a small tax burden are those with low accounting income. If income shifting happens from affiliated firms with higher income to those with lower income, propping has occurred. To summarize, internal transactions for minimizing the tax burden are important within business groups, and can occur for tunneling, propping, and group efficiency reasons.

In this study, we examine the features of affiliated companies within Korean business groups, especially those involved in income shifting through internal transactions and the directions of these internal transactions for the purpose of minimizing the tax burden. We expect that the relationships between affiliated firms are important. Decision-making for the benefit of the entire business group is affected by the relationships between affiliated firms, that is, the ownership structure between the affiliated firms. To analyze this ownership structure, we use centrality measures in a social network analysis. This method has been utilized in research in the field of sociology. Centrality, that is, the degree to which a firm is located in the center of the network of a business group, indicates the extent to which an affiliated firm is connected to other affiliates. In other words, a company with high centrality means that it owns many shares of other affiliated firms within the identical business group. Two methods are used to measure centrality: One is outdegree centrality which indicates the extent of investment in other affiliated firms, and the other is indegree centrality which indicates the degree of shareholdings which are owned by other affiliated firms.

Collins et al. (1998) and Gramlich et al. (2004) revealed that firms involved in income shifting reported lower pretax income compared to other firms in order to minimize the tax burden subject to the same marginal tax rate. In this study, we examine the direction of income shifting depending on ownership structure. We hypothesize that firms that initiate income shifting will have lower pretax income at a given marginal tax rate. In addition, firms that receive the income will have higher pretax income at the same marginal tax rate.

The results of the analysis reveal that affiliates with the higher outdegree-centrality; that is, the firms investing more shareholdings in other affiliates have a tendency to perform more income shifting. By contrast, affiliates with high indegree centrality were revealed to be awarded the income from other affiliated firms in order to minimize the tax burden of the entire business group. Based on these results, two conclusions can be drawn. First, income shifting for minimizing tax burden of the business group is usually conducted in the center of the affiliates with high centrality. Secondly, income shifting often occurs from firms with high outdegree centrality to firms with high indegree-centrality.

\section{RELATED RESEARCH AND HYPOTHESIS DEVELOPMENT}

Johnson, La Porta, Lopez-de-Silanes, and Shleifer (2000) found that the controlling shareholders behave the income shifting in a direction favorable to them but not to minority shareholders for their own private interest, which was defined as "tunneling." Furthermore, they suggest the decision of the internal shifting price, private use of firm's assets, and guarantees of debt that are favorable to controlling shareholders as types of tunneling. Bertrand et al. (2002) demonstrated that controlling shareholders pursue their own private interests as income is shifted from firms with low share ratios for controlling shareholders to firms with high share ratios. Income shifting for the 
benefit of controlling shareholders is reported to have adverse effects on firm value. Cheung, Rau, and Stouraitis (2006) showed a negative effect of tunneling on the price-earnings ratio. In that study, a lower excess earnings ratio for internal transactions between affiliated firms was associated with a higher share ratio of controlling shareholders. The analysis revealed an effect of disclosing internal transactions on the stock price of listed firms in Hong Kong. Gordon, Henry, and Palia (2004) found no effect of internal transactions in efficient internal capital markets. In that study, the price-earnings ratio decreased in firms with more vulnerable corporate governance and more frequent internal transactions. They analyzed the relationship between controlling structures and firm value by examining internal transactions between firms and board members in American firms during the period from 2000 to 2001.

However, Friedman, Johnson, and Mitton (2003) and Riyanto and Toolsema (2008) revealed that in some cases, the controlling shareholders sacrificed their own interests for ailing firms within their financial group, which is known as "propping." They proposed that firms with high debt may require more propping by controlling shareholders than firms with less debt.

Most studies of internal transactions to benefit the entire business group focused on minimization of the tax burden. Many studies have examined income shifting between firms with different tax rates or in different jurisdictions. For example, income is shifted between firms in multi-national corporations to reduce the combined tax burden by taking advantage of differences in tax rate between jurisdictions (Collins et al., 1998; Harris et al., 1993; Jacob, 1996; Klassen et al., 1993; Mills \& Newsberry, 2004). Jung, Kim, and Kim (2009) studied minimization of the tax burden via income shifting between firms subject to the same taxation authority. In that study, income was shifted from affiliates with large tax burdens to those with small tax burdens for the benefit of the entire group in Korean business group. Income shifting occurred more often as the share ratio of the controlling shareholders increased. Thus, this strategy is used to maximize benefit for the business group as a whole or for the benefit of the controlling shareholders. Such internal transactions between affiliated firms may involve goods, services, borrowing, and guarantees.

Jung, Kim, and Kim (2009) revealed that in business groups with affiliates with large tax burdens, income was shifted to affiliates with lower tax burdens to alleviate the tax burden of the entire group. Firms with high share ratios of the single largest shareholder shifted income in order to maximize the benefits to the controlling shareholders and the group as a whole. However, features of individual firms only such as the size of the tax burden and largest shareholder equity ratio were examined in this study. However, the relationships between affiliates can also influence such internal transactions within a business group. As decisions about internal transactions affect the entire business group, the relationships between affiliates are important, especially in business groups with complicated ownership structures, such as pyramidal structures and cross-shareholdings. The relationships between affiliates are formed through the purchase of shares.

In the business group, some firms have many relationships with other affiliates, while others do not. The degree to which individual firms' actions participating in maximizing the benefits of the entire business group may vary according to the intensity of their relationships with other affiliates. For firms with more relationships with other affiliated firms, internal transactions between affiliates can occur frequently.

A negative change may occur for firms whose profit is reduced as a result of income shifting. However, investing firms may gain income from the firms in which they invest. In the case of applying the equity method, the equity method income can be recognized as much as the share ratios multiplying accounting income of the invested firms. Even if the equity method is not applied, they can earn economic income from the increase of stock values of the firms awarded shareholdings or dividend. Therefore, if the firm who owns many shareholdings of their affiliates performs the income shifting, it cannot be substantially harmful economically to the individual firms and it can contribute to the interest of the entire business group. Thus, we hypothesize as follows:

Hypothesis 1: Performing income shifting will be more prevalent in firms that own more shares in other affiliated firms within the business group.

On the other hand, the firm who is awarded many shareholdings among the affiliates within the business group faces a different situation compared to the firm awarding many shareholdings. If firms that are more owned 
by other affiliates receive income, positive economic changes such as increased accounting income or stock value would be more belonging to investing companies which are also affiliates. In other words, the effect of income shifting is maximized when shifted income is given to the firms that are more owned from other affiliates within the business because shifted income still exists within the group more. Therefore, we hypothesize this:

Hypothesis 2: $\quad$ Receiving income shifting will be more prevalent in firms that are more owned from other affiliates within the business group.

\section{SAMPLE AND DATA}

\subsection{Sample}

The sample selection procedure is reported in Panel A of Table 1. The Fair Trade Commission (hereinafter referred to as the F. T. Commission) designates and presents a list of business groups yearly according to specific criteria. $^{2}$ In the sample used in this study, firms not subject to external audit and those without financial data have been excluded from the list of firms affiliated with business groups announced by the F. T. Commission from 2001 to 2010. Public enterprise conglomerates have been excluded, as their decision-making processes are different from those of other affiliates in the business group in terms of governance and ownership structure. After the exclusion of these firms, 3,788 firm-years were included in the final sample. The data on ownership structure of the firms included in the sample was extracted from the F. T. Commission report. The shareholding network structure of the group can be inferred by determining the ownership and shareholding structures of the entire group, because the data includes the ownership structure of all the affiliates belonging to the group, including all unlisted and listed firms. The financial data was collected from the KIS-VALUE database. Panel B of Table 1 shows the numbers of listed and unlisted firms in the designated sample. The number of listed firms (1,102 firm-years) accounted for $29 \%$ of the total sample. Panel $\mathrm{C}$ of Table 1 describes the industry classification of the firms in the sample. Firms in the financial business accounted for the largest part of the sample $(\mathrm{n}=353,9.3 \%)$, followed by the general construction business $(\mathrm{n}=284,7.5 \%)$, and businesses manufacturing compounds and chemical products $(\mathrm{n}=245,6.5 \%)$. For outliers, $1 \%$ winsorizing was conducted for the following variables: PTAXROA, ETR ${ }^{3} 1$, ETR2, outdegree centrality, and leverage.

Table 1: Sample Firms

\begin{tabular}{|c|c|c|c|}
\hline \multicolumn{4}{|c|}{ Panel A: Sample Selection Procedure } \\
\hline \multicolumn{4}{|c|}{$\begin{array}{l}\text { Number of sample firms from among the firms affiliated to the business group: } 9,570 \\
\text { Less the firms with no financial data on the KIS-VALUE database: } 5,411 \\
\text { (corporations not subject to external audit and firms without financial data) } \\
\text { Less public enterprises: } 371 \\
\text { Total sample: } \mathbf{3 , 7 8 8} \text { firms }\end{array}$} \\
\hline \multicolumn{4}{|c|}{ Panel B: Distribution of Sample Firms by Year } \\
\hline Year & Listed & Unlisted & All \\
\hline 2001 & 79 & 107 & 186 \\
\hline 2002 & 86 & 128 & 214 \\
\hline 2003 & 94 & 162 & 256 \\
\hline 2004 & 101 & 197 & 298 \\
\hline 2005 & 107 & 239 & 346 \\
\hline 2006 & 119 & 287 & 406 \\
\hline 2007 & 128 & 353 & 480 \\
\hline 2008 & 113 & 311 & 424 \\
\hline 2009 & 126 & 407 & 533 \\
\hline 2010 & 149 & 496 & 645 \\
\hline Total & $1102(29 \%)$ & $2686(71 \%)$ & $3788(100 \%)$ \\
\hline
\end{tabular}

\footnotetext{
${ }^{2}$ Refer to Appendix 1.

${ }^{3}$ We use the abbreviation PTAXROA to indicate the pretax return on assets and ETR to indicate the effective tax rate.
} 
Table 1 cont.

\begin{tabular}{lcc}
\hline Panel C: Distribution of Sample Firms by Industry & & \% \\
\hline \multicolumn{1}{c}{ Industry } & $\mathbf{N}$ & $4.0 \%$ \\
\hline Food Products and Beverages & 152 & $0.6 \%$ \\
Textiles & 23 & $0.3 \%$ \\
Pulp, Paper, and Paper Products & 10 & $6.5 \%$ \\
Chemicals and Chemical Products & 245 & $2.6 \%$ \\
Rubber and Plastic Products & 97 & $4.2 \%$ \\
Basic Metals & 159 & $3.8 \%$ \\
Electronic Components, Radio, Television, and & 144 & $4.8 \%$ \\
Communication Equipment and Apparatus & 183 & $4.0 \%$ \\
Other Machinery and Equipment & 153 & $3.7 \%$ \\
Motor Vehicles, Trailers, and Semitrailers & 140 & $7.5 \%$ \\
Electricity, Gas, Steam, and Hot Water Supply & 284 & $5.5 \%$ \\
Construction & 209 & $5.1 \%$ \\
Wholesale & 192 & $3.8 \%$ \\
Retail Trader (Excluding Motor Vehicles) & 1,444 & $9.3 \%$ \\
Other Services & 353 & 100 \\
Finance & 3,788 & \\
\hline
\end{tabular}

\subsection{Empirical Model and Variables}

For verification of Hypothesis 1 (performing income shifting will be more prevalent in firms that own more shares in other affiliated firms within the business group) and Hypothesis 2 (receiving income shifting will be more prevalent in firms that are more owned from other affiliates within the business group), we examine the relationship between pretax income rates (which show profitability) and effective tax rates (which indicate the tax burden). In general, pretax income rates and effective tax rates are in a positive relationship (Rego, 1999). Internal transactions between affiliated firms such as sales and purchasing of goods, receipt and payment of commission fees for services, and interest income and expenses incurred through trading on equity, have an effect on the pretax income of firms that are shifting income and those receiving income. The degree of positivity of the relationship between effective and pretax tax rates is reflected in the relationship between these two types of firms. According to Collins et al. (1998) and Gramlich et al. (2004), firms performing income shifting reported lower pretax income rates at the same effective tax rates compared to firms that did not income shifting. Therefore, firms awarding income shifting will report lower pretax income rates than firms with the same effective tax rates that are not involved in income shifting. On the other hand, firms receiving income will report higher pretax income rates than firms not receiving income at the same effective tax rates.

In this study, social network analysis is used to analyze ownership structure between affiliates within one business group. Previous studies, mainly in the field of sociology, have used social network analysis to measure the degree of crossover shareholding between affiliated firms. Recently, this method has been used as a tool to analyze business groups Choi (2009) analyzed the ownership structure of business groups using social network analysis.

We measure centrality by describing the role of specific firms within a business group using social network analysis. Centrality is an index representing the proximity of a given performer to the center of the entire network, and its connection to other performers. Thus, centrality measures the number of direct connections. It has often been used as a measure of influence in sociology research. Centrality may occur in two directions. For outdegree centrality, the direction of exchange is outwards, and for indegree centrality, connections come in from outside. In this study, we define outdegree centrality as the number of shares held by other affiliates within the business group. Outdegree centrality is the sum of equity rates owned by individual firms in other affiliates (see Equation 1). Therefore, as outdegree centrality increases, firms have more shares of other affiliates within the business group. For instance, a holding company that awards shares to all its subsidiary companies has high outdegree centrality.

oUTdegree $_{i}=\sum_{j \neq i}$ Interest $_{i j}$

where interest is the sum of simple equity rates invested in each affiliate. 
Indegree centrality reflects the shareholding relationship within the business group, which is the sum of equity rates that an individual firm is awarded from affiliated firms within the group. The calculation is shown in Equation 2:

INdegree $_{i}=\sum_{j \neq i}$ Interest $_{i j}$

where interest is the sum of simple equity rates being invested from each affiliate.

Based on this concept, we develop the following study model to verify Hypothesis 1 (performing income shifting will be more prevalent in firms that own more shares in other affiliated firms within the business group) (Equation 3):

PTAXROA $=\alpha 0+\alpha 1$ ETR $+\alpha 2($ ETR $*$ OUTDEGREE $)+\alpha 3$ UUTDEGREE $+\alpha 4$ LARGEST $+\alpha 5$ SIZE + $\alpha 6$ LEVERAGE $+\alpha 7$ Group dummy $+\alpha 8$ Industry dummy $+\alpha 9$ Year dummy $+\varepsilon$

where PTAXROA(pretax return on assets) is measured as the ratio of the pretax income to total underlying assets.

We use the abbreviation ETR to indicate the effective tax rate as a proxy for tax burden, which means the corporate tax that the firms actually pay. In this study, the effective tax rate is measured in two ways. ETR1 is the amounts of tax payable that one corporation reports divided by pre-tax income. ETR2 is the amount of corporate tax expenses divided by pre-tax income, including deferred corporate taxes, influencing future corporate tax due to events occurring during the current term, as well as the corporate tax actually paid in the current year, compared to the pretax income. We additionally used the dummy variables ABOVEETR1 and ABOVEETR2 after dividing ETR1 and ETR2 by the median; giving it a value of 1 if it is larger than the median, and otherwise giving it a value of 0 . For OUTDEGREE, which shows the degree of shareholding among affiliates, two values are used: the actual values and a standardized value to control for differences in shareholding structure for each group. NRM_OUTDEGREE, as a value standardizing OUTDEGREE, is shown as Equation 4:

NRM_OUTDEGREE $\quad=\frac{\text { OUTDEGREE-Mean of OUTDEGREEof Group i }}{\text { Standard deviation }}$

As Hypothesis 1 is that performing income shifting will be more prevalent in firms that own more shares in other affiliated firms within the business group, the interaction values (ETR $*$ OUTDEGREE) of the tax burden proxy (ETR) and OUTDEGREE, which show the degree of shareholding to affiliated firms, are expected to have a negative relationship with the pretax income rates $(\alpha 2<0)$. That is, because income shifting performs more frequently in firms with a high outdegree, PTAXROA will be lower compared to ETR. In order to verify Hypothesis 2 (receiving income shifting will be more prevalent in firms receiving investment and many shares from other affiliates within the business group) we present Equation 5:

PTAXROA $=\beta 0+\beta 1$ ETR $+\beta 2($ ETR $*$ INDEGREE $)+\beta 3$ INDEGREE $+\beta 4$ LARGEST $+\beta$ SSIZE $+\beta 6$ LEVERAGE +

$\beta 7$ Group dummy $+\beta 8$ Industry dummy $+\beta$ YYear dummy $+\varepsilon$

The tax burden proxy (ETR) is measured as in Equation 3, which was used to verify Hypothesis 1. INDEGREE, which shows the degree of investment from affiliated firms, uses two values as also used for OUTDEGREE: the actual values and a standardized value to control for the differences in the shareholding structure between groups. NRM_INDEGREE, a value standardizing INDEGREE, is shown in Equation 6:

NRM_INDEGREE $=\frac{\text { OUTDEGREE-Mean of INDEGREEof Group i }}{\text { Standard deviation }}$

As Hypothesis 2 is receiving income shifting will be more prevalent in firms receiving investment and many shares from other affiliates within the business group, the interaction values (ETR $*$ indegree) of the tax

${ }^{4}$ Firms with year-end in December must include the appropriate corporate tax amount that must be paid before the end of next March as income
tax payable in a balance sheet of the end of the year. Copyright by author(s); CC-BY 
burden proxy (ETR) and INDEGREE, which shows the degree of investment by affiliated firms, is expected to have a positive relationship $(\beta 2>0)$. That is, because income shifting are received more frequently in firms with a high indegree, the pretax income rate is expected to increase compared to the ETR.

The control variables in Equations 3 and 5 are as follows. According to Jung, Kim, and Kim (2009), in business groups, the ratio of shares belonging to controlling shareholders should be considered a control variable. In addition, a group dummy ${ }^{5}$ has been included in this study to control for differences between business groups since income shifting is often used to maximize income in the business group as a whole, alleviating tax burdens. Other control variables include company size (SIZE), which is a natural logarithm value of total underlying assets, LEVERAGE (debt divided by assets), an industry dummy, and a year dummy. A summary of all variables is provided in Table 2 .

Table 2: Variables

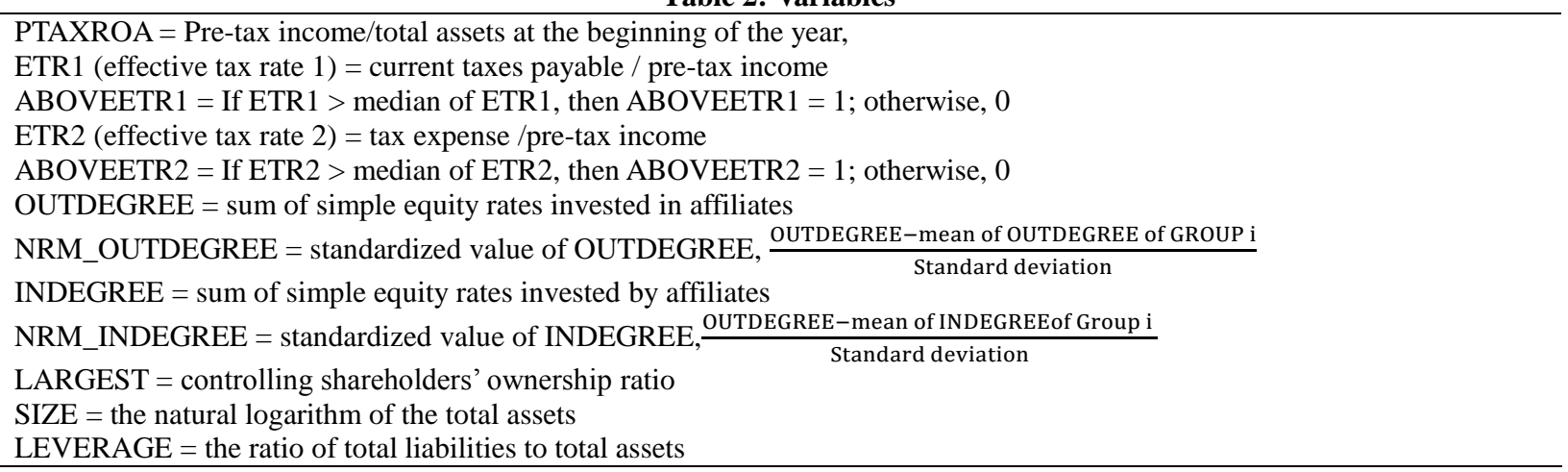

\section{EMPIRICAL RESULTS}

\subsection{Descriptive Statistics and Correlation Analysis of Major Variables}

Table 3 shows the descriptive statistics of the variables used in this study. The mean and median of PTAXROA are, respectively, 0.0491 and 0.0440 . The mean (median) of ETR1 and ETR2 indicating the corporate tax burden are respectively 0.1012(0.0587) and 0.1686(0.2294). As the mean of OUTDEGREE, which is the sum of equity rates invested in affiliated firms, is 78.7951 , firms belonging to the business group possess the equity rates equivalent to $78.7951 \%$ of the affiliated firms on average. However, because the median of OUTDEGREE is 0 , the standard deviation must be large because half the firms belonging to the business group do not own shares in other affiliates. Also, because INDEGREE, which is the sum of equity rates invested by affiliates, is $57.0247,57.0247 \%$ of the stock of firms belonging to the business group must be owned by affiliated firms.

Table 3: Descriptive Statistics

\begin{tabular}{lccccc}
\hline \multicolumn{1}{c}{ Variable } & Mean & Std. & Q1 & Median & Q3 \\
\hline PTAXROA & 0.0491 & 0.1633 & 0.0017 & 0.0440 & 0.1125 \\
ETR1 & 0.1012 & 0.1563 & 0.0000 & 0.0587 & 0.1698 \\
ABOVEETR1 & 0.5000 & 0.5001 & 0.0000 & 0.5000 & 1.0000 \\
ETR2 & 0.1686 & 0.2461 & 0.0000 & 0.2294 & 0.2827 \\
ABOVEETR2 & 0.5000 & 0.5001 & 0.0000 & 0.5000 & 1.0000 \\
OUTDEGREE & 78.7951 & 164.5714 & 0.0000 & 0.0000 & 80.3500 \\
NRM_OUTDEGREE & 4.1181 & 10.8535 & 0.0000 & 0.0000 & 2.4630 \\
INDEGREE & 57.0247 & 34.0798 & 30.0650 & 51.8600 & 96.1400 \\
NRM_INDEGREE & 2.7378 & 5.5223 & 0.8390 & 1.6670 & 3.1050 \\
LARGEST & 0.0504 & 0.1523 & 0.0000 & 0.0000 & 0.0071 \\
SIZE & 25.9572 & 2.0841 & 24.4081 & 25.7013 & 27.4488 \\
LEVERAGE & 0.5509 & 0.2666 & 0.3651 & 0.5610 & 0.7209 \\
\hline
\end{tabular}

For the definition of variables, refer to Table 2.

${ }^{5}$ The 65 largest conglomerates are included in the sample. 
Table 4 shows that the positive correlations between PTAXROA and ETR1 and between PTAXROA and ETR2 both indicate that pretax income rates and tax burden are in a positive relationship. The positive correlation between ETR2 and OUTDEGREE indicates that firms that own many shares have a large tax burden, as ETR is high. The negative correlation between ETR2 and INDEGREE indicates that firms that are invested in many shares from other affiliates have a small tax burden. From the positive correlation between SIZE and OUTDEGREE and the negative correlation between SIZE and INDEGREE, we can infer that the affiliates investing many shares are large companies, and the affiliates being invested many shares from other affiliates are relatively small.

Table 4: Correlations among Variables

\begin{tabular}{lccccc}
\hline & ETR1 & ETR2 & OUTDEGREE & INDEGREE & Size \\
\hline \multirow{2}{*}{ PTAXROA } & 0.1992 & 0.1799 & -0.0138 & 0.0070 & -0.0435 \\
& $(<0.0001)$ & $(<0.0001)$ & $(0.3958)$ & $(0.6687)$ & $(0.0075)$ \\
ETR1 & & 0.2934 & 0.0130 & -0.0150 & 0.0406 \\
& & $(<0.0001)$ & $(0.4242)$ & $(0.3548)$ & $(0.0125)$ \\
ETR2 & & 0.0668 & -0.0796 & 0.0644 \\
& & & $(<.0001)$ & $(<.0001)$ & $(<.0001)$ \\
OUTDEGREE & & & -0.4166 & 0.4826 \\
& & & & $(<.0001)$ & $(<.0001)$ \\
INDEGREE & & & & & -0.3958 \\
& & & & & $(<.0001)$ \\
\hline
\end{tabular}

For the definition of variables, refer to Table 2.

\subsection{Results of Regression Analysis}

The results of the regression analysis for verification of Hypothesis 1 (performing income shifting will be more prevalent in firms that own more shares in other affiliated firms within the business group) are represented in Tables 5 and 6. Table 5 shows the results of the regression analysis using OUTDEGREE (not standardized as the independent variable), ETR1 (Panel A), ETR2 (Panel C), ABOVEETR1 (Panel B), and ABOVEETR2 (Panel D). All coefficients of the effective tax rates in Panels A D of Table 5 indicate positive values significant at the $1 \%$ level. These results support those of previous studies, which indicated that the tax burden increases as the pretax income rates increase. Also, the coefficients $(\alpha 2)$ of the interaction variables (ETR * OUTDEGREE) of the tax burden and the degree of shareholdings, which are the key variables for verification of Hypothesis 1, are negative and significant at the 5\% level in Panels A C and at the 1\% level in Panel D of Table 5. Therefore, this result supports Hypothesis 1. Table 6 shows the results of the analysis using NRM_OUTDEGREE, which is OUTDEGREE standardized to consider differences in shareholding structure among groups. The results are similar to those with Table 5. Therefore, when the results presented in Tables 5 and 6 are combined, we see that performing income shifting occurs more frequently in firms that own more shares in affiliates within the business group.

Table 5: Results of Multivariate Regression Analyses

Panel A: Regression Results Using Effective Tax Rate 1 and Outdegree

$$
\text { PTAXROA }=\alpha 0+\alpha 1 \text { ETR } 1+\alpha 2 \text { (ETR } 1 * \text { OUTDEGREE })+\alpha 3 \text { OUTDEGREE }+\alpha 4 \text { LARGEST }+\alpha 5 \text { SIZE }+\alpha 6 \text { LEVERAGE }
$$
$+\alpha 7$ Group dummy $+\alpha 8$ Industry dummy $+\alpha 9$ Year dummy $+\varepsilon$

\begin{tabular}{|c|c|c|c|c|c|c|}
\hline Variable & Coefficient & Standard Error & t-statistic & Coefficient & Standard Error & t-statistic \\
\hline Intercept & -0.04825 & 0.04068 & -1.19 & -0.05090 & 0.04067 & -1.25 \\
\hline ETR1 & 0.17792 & 0.01580 & $11.26 * * *$ & 0.19609 & 0.01776 & $11.04 * * *$ \\
\hline ETR1*OUTDEGREE & & & & -0.00021 & 0.00009 & $-2.24 * *$ \\
\hline OUTDEGREE & -0.00001 & 0.00002 & -0.62 & 0.00001 & 0.00002 & 0.47 \\
\hline LARGEST & 0.07353 & 0.01972 & $3.73 * * *$ & 0.07364 & 0.01971 & $3.74 * * *$ \\
\hline SIZE & -0.00062 & 0.00156 & -0.40 & -0.00058 & 0.00156 & -0.37 \\
\hline LEVERAGE & -0.11561 & 0.00974 & $-11.86 * * *$ & -0.11549 & 0.00974 & $-11.86 * * *$ \\
\hline Group dummy & include & & & include & & \\
\hline Industry dummy & include & & & include & & \\
\hline Year dummy & include & & & include & & \\
\hline $\mathrm{N}$ & 3788 & & & 3788 & & \\
\hline F-value for the model & 13.37 & & & 13.29 & & \\
\hline (p-value) & $(<.0001)$ & & & $(<.0001)$ & & \\
\hline $\mathrm{R}^{2}$ & 0.2240 & & & 0.2295 & & \\
\hline
\end{tabular}


Table 5 cont.

\begin{tabular}{|c|c|c|c|c|c|c|}
\hline \multicolumn{7}{|c|}{$\begin{array}{l}\text { Panel B: Regression Results Using the Effective Tax Rate Dummy } 1 \text { and Outdegree } \\
\begin{array}{r}\text { PTAXROA }=\alpha 0+\alpha 1 \text { ABOVEETR } 1+\alpha 2(\text { ABOVEETR } 1 * \text { OUTDEGREE })+\alpha 30 \text { UTDEGREE }+\alpha 4 \text { LARGEST }+\alpha 5 \text { SIZE } \\
+\alpha 6 \text { LEVERAGE }+\alpha \text { Group dummy }+\alpha 8 \text { Industry dummy }+\alpha 9 \text { Year dummy }+\varepsilon\end{array}\end{array}$} \\
\hline Variable & Coefficient & $\begin{array}{c}\text { Standard } \\
\text { Error }\end{array}$ & t-statistic & Coefficient & $\begin{array}{c}\text { Standard } \\
\text { Error }\end{array}$ & t-statistic \\
\hline Intercept & -0.04491 & 0.03877 & -1.16 & -0.04636 & 0.03876 & -1.2 \\
\hline ABOVEETR1 & 0.10655 & 0.00486 & $21.93 * * *$ & 0.11152 & 0.00533 & $20.94 * * *$ \\
\hline ABOVEETR $1 *$ OUTDEGREE & & & & -0.00006 & 0.00003 & $-2.27 * *$ \\
\hline OUTDEGREE & 0.00000 & 0.00002 & -0.09 & 0.00003 & 0.00002 & 1.43 \\
\hline LARGEST & 0.06354 & 0.01890 & $3.36 * * *$ & 0.06437 & 0.01890 & $3.41 * * *$ \\
\hline SIZE & -0.00329 & 0.00149 & $-2.20 * *$ & -0.00336 & 0.00149 & $-2.25 * *$ \\
\hline LEVERAGE & -0.08496 & 0.00944 & $-9.00 * * *$ & -0.08452 & 0.00944 & $-8.96 * * *$ \\
\hline Group dummy & include & & & include & & \\
\hline Industry dummy & include & & & include & & \\
\hline Year dummy & include & & & include & & \\
\hline $\mathrm{N}$ & 3788 & & & 3788 & & \\
\hline F-value for the model & 18.75 & & & 18.61 & & \\
\hline (p-value) & $(<.0001)$ & & & $(<.0001)$ & & \\
\hline $\mathrm{R}^{2}$ & 0.2933 & & & 0.2943 & & \\
\hline
\end{tabular}

Panel C: Regression Results Using the Effective Tax Rate 2 and Outdegree

PTAXROA $=\alpha 0+\alpha 1$ ETR $2+\alpha 2($ ETR $2 *$ OUTDEGREE $)+\alpha 3$ OUTDEGREE $+\alpha 4$ LARGEST $+\alpha 5$ SIZE $+\alpha 6$ LEVERAGE $+\alpha 7$ Group dummy $+\alpha 8$ Industry dummy $+\alpha 9$ Year dummy $+\varepsilon$

\begin{tabular}{|c|c|c|c|c|c|c|}
\hline Variable & Coefficient & $\begin{array}{c}\text { Standard } \\
\text { Error }\end{array}$ & t-statistic & Coefficient & $\begin{array}{c}\text { Standard } \\
\text { Error }\end{array}$ & t-statistic \\
\hline Intercept & -0.03828 & 0.04061 & -0.94 & -0.04099 & 0.04059 & -1.01 \\
\hline ETR2 & 0.10570 & 0.01006 & $10.51 * * *$ & 0.11972 & 0.01129 & $10.60 * * *$ \\
\hline ETR2*OUTDEGREE & & & & -0.00018 & 0.00007 & $-2.72 * *$ \\
\hline OUTDEGREE & -0.00002 & 0.00002 & -1.08 & 0.00002 & 0.00002 & 0.75 \\
\hline LARGEST & 0.07366 & 0.01980 & $3.72 * * *$ & 0.07262 & 0.01979 & $3.67 * * *$ \\
\hline SIZE & -0.00125 & 0.00156 & -0.80 & -0.00133 & 0.00156 & -0.86 \\
\hline LEVERAGE & -0.11102 & 0.00979 & $-11.35 * * *$ & -0.10946 & 0.00979 & $-11.18 * * *$ \\
\hline Group dummy & include & & & include & & \\
\hline Industry dummy & include & & & include & & \\
\hline Year dummy & include & & & include & & \\
\hline $\mathrm{N}$ & 3788 & & & 3788 & & \\
\hline F-value for the model & 13.09 & & & 13.05 & & \\
\hline (p-value) & $(<.0001)$ & & & $(<.0001)$ & & \\
\hline $\mathrm{R}^{2}$ & 0.2247 & & & 0.2262 & & \\
\hline
\end{tabular}

Panel D: Regression Results Using the Effective Tax Rate Dummy 2 and Outdegree

PTAXROA $=\alpha 0+\alpha 1$ ABOVEETR $2+\alpha 2$ (ABOVEETR $2 *$ OUTDEGREE $)+\alpha 3$ OUTDEGREE $+\alpha 4$ LARGEST $+\alpha 5$ SIZE $+\alpha 6$ LEVERAGE $+\alpha 7$ Group dummy $+\alpha 8$ Industry dummy $+\alpha 9$ Year dummy $+\varepsilon$

\begin{tabular}{|c|c|c|c|c|c|c|}
\hline Variable & Coefficient & $\begin{array}{c}\text { Standard } \\
\text { Error }\end{array}$ & t-statistic & Coefficient & $\begin{array}{c}\text { Standard } \\
\text { Error }\end{array}$ & t-statistic \\
\hline Intercept & -0.03467 & 0.04007 & -0.87 & -0.05360 & 0.04015 & -1.33 \\
\hline ABOVEETR2 & 0.07475 & 0.00509 & $14.68 * * *$ & 0.08581 & 0.00559 & $15.34 * * *$ \\
\hline ABOVEETR $2 *$ OUTDEGREE & & & & -0.00014 & 0.00003 & $-4.70 * * *$ \\
\hline OUTDEGREE & -0.00001 & 0.00002 & -0.32 & 0.00006 & 0.00002 & $2.57 * *$ \\
\hline LARGEST & 0.06731 & 0.01954 & $3.44 * * *$ & 0.06232 & 0.01952 & $3.19 * * *$ \\
\hline SIZE & -0.00284 & 0.00155 & $-1.84 *$ & -0.00260 & 0.00154 & $-1.68 *$ \\
\hline LEVERAGE & -0.10659 & 0.00966 & $-11.04 * * *$ & -0.10372 & 0.00965 & $-10.75 * * *$ \\
\hline Group dummy & include & & & include & & \\
\hline Industry dummy & include & & & include & & \\
\hline Year dummy & include & & & include & & \\
\hline $\mathrm{N}$ & 3788 & & & 3788 & & \\
\hline F-value for the model & 14.70 & & & 14.87 & & \\
\hline (p-value) & $(<.0001)$ & & & $(<.0001)$ & & \\
\hline $\mathrm{R}^{2}$ & 0.2455 & & & 0.2500 & & \\
\hline
\end{tabular}


Table 6: Results of Multivariate Regression Analyses

\begin{tabular}{|c|c|c|c|c|c|c|}
\hline \multicolumn{7}{|c|}{ Panel A: Regression Results Using the Effective Tax Rate 1 and Nrm_Outdegree } \\
\hline \multicolumn{7}{|c|}{$\begin{array}{c}\text { PTAXROA }=\alpha 0+\alpha 1 \text { ETR } 1+\alpha 2(\text { ETR } 1 * \text { Nrm_Outdegree })+\alpha 3 \text { Nrm_Outdegree }+\alpha 4 \text { LARGEST }+\alpha 5 \text { SIZE } \\
+\alpha 6 \text { LEVERAGE }+\alpha 7 \text { Group dummy }+\alpha 8 \text { Industry dummy }+\alpha 9 \text { Year dummy }+\varepsilon\end{array}$} \\
\hline Variable & Coefficient & Standard Error & t-statistic & Coefficient & Standard Error & t-statistic \\
\hline Intercept & -0.02530 & 0.03897 & -0.65 & -0.02703 & 0.03895 & -0.69 \\
\hline ETR1 & 0.17816 & 0.01566 & $11.38 * * *$ & 0.19379 & 0.01695 & $11.43 * * *$ \\
\hline $\begin{array}{l}\text { ETR } 1 * \\
\text { NRM OUTDEGREE }\end{array}$ & & & & -0.00363 & 0.00152 & $-2.39 * *$ \\
\hline NRM_OUTDEGREE & 0.00016 & 0.00028 & 0.55 & 0.00055 & 0.00033 & $1.68 *$ \\
\hline LARGEST & 0.07814 & 0.01988 & $3.93 * * *$ & 0.08069 & 0.01989 & $4.06 * * *$ \\
\hline SIZE & -0.00185 & 0.00147 & -1.26 & -0.00187 & 0.00147 & -1.28 \\
\hline LEVERAGE & -0.11278 & 0.00966 & $-11.67 * * *$ & -0.11180 & 0.00967 & $-11.57 * * *$ \\
\hline Group dummy & include & & & include & & \\
\hline Industry dummy & include & & & include & & \\
\hline Year dummy & include & & & include & & \\
\hline $\mathrm{N}$ & 3788 & & & 3788 & & \\
\hline F-value for the model & 13.37 & & & 13.29 & & \\
\hline (p-value) & $(<.0001)$ & & & $(<.0001)$ & & \\
\hline $\mathrm{R}^{2}$ & 0.2283 & & & 0.2295 & & \\
\hline
\end{tabular}

Panel B: Regression Results Using the Effective Tax Rate dummy 1 and Nrm_Outdegree

PTAXROA $=\alpha 0+\alpha 1$ ABOVEETR $1+\alpha 2($ ABOVEETR $1 *$ Nrm_Outdegree $)+\alpha 3$ Nrm_Outdegree $+\alpha 4$ LARGEST $+\alpha 5$ SIZE $+\alpha 6$ LEVERAGE $+\alpha 7$ Group dummy $+\alpha 8$ Industry dummy $+\alpha 9$ Year dummy $+\varepsilon$

\begin{tabular}{|c|c|c|c|c|c|c|}
\hline Variable & Coefficient & Standard Error & t-statistic & Coefficient & Standard Error & t-statistic \\
\hline Intercept & -0.02997 & 0.03729 & -0.8 & -0.03206 & 0.03724 & -0.86 \\
\hline ABOVEETR1 & 0.10675 & 0.00486 & $21.99 * * *$ & 0.11233 & 0.00514 & $21.85^{* * *}$ \\
\hline $\begin{array}{l}\text { ABOVEETR1* } \\
\text { NRM_OUTDEGREE }\end{array}$ & & & & -0.00146 & 0.00045 & $-3.27 * * *$ \\
\hline NRM_OUTDEGREE & 0.00028 & 0.00027 & 1.05 & 0.00105 & 0.00036 & $2.94 * *$ \\
\hline LARGEST & 0.06588 & 0.01903 & $3.46 * * *$ & 0.07241 & 0.01911 & $3.79 * * *$ \\
\hline SIZE & -0.00401 & 0.00141 & $-2.85 * *$ & -0.00410 & 0.00141 & $-2.91 * *$ \\
\hline LEVERAGE & -0.08358 & 0.00937 & $-8.92 * * *$ & -0.08224 & 0.00937 & $-8.78 * * *$ \\
\hline Group dummy & Include & & & include & & \\
\hline Industry dummy & Include & & & include & & \\
\hline Year dummy & Include & & & include & & \\
\hline $\mathrm{N}$ & 3788 & & & 3788 & & \\
\hline F-value for the model & 18.77 & & & 18.72 & & \\
\hline (p-value) & $(<.0001)$ & & & $(<.0001)$ & & \\
\hline $\mathrm{R}^{2}$ & 0.2935 & & & 0.2955 & & \\
\hline
\end{tabular}

Panel C: Regression Results Using the Effective Tax Rate 2 and Nrm_Outdegree

PTAXROA $=\alpha 0+\alpha 1$ ETR2 $+\alpha 2(E T R 2 *$ Nrm_Outdegree $)+\alpha 3$ Nrm_Outdegree $+\alpha 4$ LARGEST $+\alpha 5$ SIZE $+\alpha 6$ LEVERAGE $+\alpha 7$ Group dummy $+\alpha 8$ Industry dummy $+\alpha 9$ Year dummy $+\varepsilon$

\begin{tabular}{|c|c|c|c|c|c|c|}
\hline Variable & Coefficient & $\begin{array}{c}\text { Standard } \\
\text { Error }\end{array}$ & t-statistic & Coefficient & $\begin{array}{c}\text { Standard } \\
\text { Error }\end{array}$ & t-statistic \\
\hline Intercept & -0.01530 & 0.03907 & -0.39 & -0.01552 & 0.03904 & -0.4 \\
\hline ETR2 & 0.10571 & 0.01006 & $10.51 * * *$ & 0.11647 & 0.01096 & $10.63 * * *$ \\
\hline ETR2*NRM_OUTDEGREE & & & & -0.00277 & 0.00113 & $-2.46 * *$ \\
\hline NRM_OUTDEGREE & 0.00009 & 0.00028 & 0.31 & 0.00067 & 0.00037 & $1.82 *$ \\
\hline LARGEST & 0.07414 & 0.01995 & $3.72 * * *$ & 0.07428 & 0.01993 & $3.73 * * *$ \\
\hline SIZE & -0.00234 & 0.00148 & -1.59 & -0.00248 & 0.00148 & $-1.68 *$ \\
\hline LEVERAGE & -0.10891 & 0.00972 & $-11.20 * * *$ & -0.10738 & 0.00974 & $-11.03 * * *$ \\
\hline Group dummy & include & & & include & & \\
\hline Industry dummy & include & & & include & & \\
\hline Year dummy & include & & & include & & \\
\hline $\mathrm{N}$ & 3788 & & & 3788 & & \\
\hline F-value for the model & 13.08 & & & 13.01 & & \\
\hline (p-value) & $(<.0001)$ & & & $(<.0001)$ & & \\
\hline $\mathrm{R}^{2}$ & 0.2244 & & & 0.2257 & & \\
\hline
\end{tabular}


Table 6 cont.

\begin{tabular}{|c|c|c|c|c|c|c|}
\hline $\begin{array}{r}\text { Panel D: Regression I } \\
\text { PTAXROA }=\alpha 0\end{array}$ & $\begin{array}{l}\text { sing the Effec } \\
\text { OVEETR } 2+c \\
\mathrm{ZE}+\alpha 6 \mathrm{LEV}\end{array}$ & $\begin{array}{l}\text { Tax Rate d } \\
\text { BOVEETR } \\
\text { GE }+\alpha 7 \mathrm{Gr}\end{array}$ & $\begin{array}{l}\text { ay } \mathbf{2} \text { and } \mathbf{N r} \\
\text { Jrm_Outdeg } \\
\text { dummy }+\alpha \varepsilon\end{array}$ & $\begin{array}{l}\text { Outdegree } \\
+\alpha 3 \mathrm{Nrm}_{-} \mathrm{O} \\
\text { ustry dummy }\end{array}$ & $\begin{array}{l}\text { gree }+\alpha 4 \mathrm{~L} \\
9 \text { Year dumn }\end{array}$ & $\begin{array}{l}\text { GEST } \\
+\varepsilon \\
\end{array}$ \\
\hline Variable & Coefficient & $\begin{array}{l}\text { Standard } \\
\text { Error }\end{array}$ & t-statistic & Coefficient & $\begin{array}{l}\text { Standard } \\
\text { Error }\end{array}$ & t-statistic \\
\hline Intercept & -0.01862 & 0.03853 & -0.48 & -0.02711 & 0.03855 & -0.70 \\
\hline ABOVEETR2 & 0.07499 & 0.00509 & $14.74 * * *$ & 0.08159 & 0.00542 & $15.05 * * *$ \\
\hline $\begin{array}{l}\text { ABOVEETR } 2 * \\
\text { NRM_OUTDEGREE }\end{array}$ & & & & -0.00162 & 0.00047 & $-3.45^{* * *}$ \\
\hline NRM_OUTDEGREE & 0.00022 & 0.00028 & 0.8 & 0.00113 & 0.00038 & $2.97 * *$ \\
\hline LARGEST & 0.06906 & 0.01968 & $3.51 * * *$ & 0.06578 & 0.01967 & $3.34 * * *$ \\
\hline SIZE & -0.00362 & 0.00146 & $-2.48 * *$ & -0.00366 & 0.00146 & $-2.51 * *$ \\
\hline LEVERAGE & -0.10511 & 0.00959 & $-10.96 * * *$ & -0.10228 & 0.00961 & $-10.64 * * *$ \\
\hline Group dummy & include & & & include & & \\
\hline Industry dummy & include & & & include & & \\
\hline Year dummy & include & & & include & & \\
\hline $\mathrm{N}$ & 3788 & & & 3788 & & \\
\hline F-value for the model & 14.71 & & & 14.72 & & \\
\hline (p-value) & $(<.0001)$ & & & $(<.0001)$ & & \\
\hline $\mathrm{R}^{2}$ & 0.2456 & & & 0.2480 & & \\
\hline
\end{tabular}

The results of the regression analysis that verified Hypothesis 2 (receiving income shifting will be more prevalent in firms receiving investment and many shares from other affiliates within the business group) are shown in Tables 7 and 8. Table 7 shows the results of the regression analysis using INDEGREE (not standardized) as the independent variable and ETR1 (Panel A), ETR2 (Panel C), ABOVEETR1 (Panel B), and ABOVEETR2 (Panel D). All coefficients of the effective tax rates in Panels A D of Table 7 indicate positive values significant at the $1 \%$ level. Here, the results support those of previous studies, which found a positive relationship between the pretax income and effective tax rates. The coefficients of the interaction variables (ETR * INDEGREE) of the extent of being invested from other affiliates and the tax burden shown in Table 7, which is a key variable in verification of Hypothesis 2, indicate negative values significant at the 5\% level in Panels B and D. Table 8 shows the results of the analysis using NRM_INDEGREE, which is INDEGREE standardized to consider differences in shareholding structures between groups. The coefficients $(\beta 2)$ of the interaction variables (ETR*INDEGREE) of the tax burden and the extent of shareholdings invested are positive and significant at the 5\% level in Panels A and C. Since the results presented in Tables 7 and 8 support $\mathrm{H} 2$, we see that receiving income shifting is more common in firms in which more shares are purchased by affiliates within the business group.

Table 7: Results of Multivariate Regression Analyses

Panel A: Regression Results Using the Effective Tax Rate 1 and Indegree

PTAXROA $=\alpha 0+\beta 1$ ETR $1+\beta 2($ ETR $1 *$ INDEGREE $)+\beta 3$ INDEGREE $+\beta 4$ LARGEST $+\beta 5$ SIZE $+\beta 6$ LEVERAGE $+\beta 7$ Group dummy $+\beta 8$ Industry dummy $+\beta 9$ Year dummy $+\varepsilon$

\begin{tabular}{|c|c|c|c|c|c|c|}
\hline Variable & Coefficient & $\begin{array}{c}\text { Standard } \\
\text { Error }\end{array}$ & t-statistic & Coefficient & $\begin{array}{c}\text { Standard } \\
\text { Error }\end{array}$ & t-statistic \\
\hline Intercept & -0.04511 & 0.04094 & -1.10 & -0.04335 & 0.04102 & -1.06 \\
\hline ETR1 & 0.17770 & 0.01565 & $11.35 * * *$ & 0.15903 & 0.03051 & $5.21 * * *$ \\
\hline ETR1*INDEGREE & & & & 0.00031 & 0.00044 & 0.71 \\
\hline INDEGREE & 0.00006 & 0.00008 & 0.68 & 0.00003 & 0.00009 & 0.27 \\
\hline LARGEST & 0.07904 & 0.02000 & $3.95 * * *$ & 0.07907 & 0.02000 & $3.95 * * *$ \\
\hline SIZE & -0.00109 & 0.00145 & -0.75 & -0.00109 & 0.00145 & -0.75 \\
\hline LEVERAGE & -0.11435 & 0.00969 & $-11.81 * * *$ & -0.11426 & 0.00969 & $-11.79 * * *$ \\
\hline Group dummy & Include & & & Include & & \\
\hline Industry dummy & Include & & & Include & & \\
\hline Year dummy & Include & & & Include & & \\
\hline $\mathrm{N}$ & 3788 & & & 3788 & & \\
\hline F-value for the model & 13.37 & & & 13.21 & & \\
\hline (p-value) & $(<.0001)$ & & & $(<.0001)$ & & \\
\hline $\mathrm{R}^{2}$ & 0.2283 & & & 0.2284 & & \\
\hline
\end{tabular}


Table 7 cont.

\begin{tabular}{|c|c|c|c|c|c|c|}
\hline \multicolumn{7}{|c|}{$\begin{array}{l}\text { Panel B: Regression Results Using the Effective Tax Rate Dummy } 1 \text { and Indegree } \\
\begin{aligned} \text { PTAXROA }= & \beta 0+\beta 1 \text { ABOVEETR } 1+\beta 2(\text { ABOVEETR } 1 * \text { INDEGREE })+\beta 3 \text { INDEGREE }+\beta 4 \text { LARGEST }+\beta 5 \text { SIZE } \\
& +\beta 6 \text { LEVERAGE }+\beta 7 \text { Group dummy }+\beta 8 \text { Industry dummy }+\beta 9 \text { Year dummy }+\varepsilon\end{aligned}\end{array}$} \\
\hline Variable & Coefficient & $\begin{array}{c}\text { Standard } \\
\text { Error }\end{array}$ & t-statistic & Coefficient & $\begin{array}{c}\text { Standard } \\
\text { Error }\end{array}$ & t-statistic \\
\hline Intercept & -0.05196 & 0.03918 & -1.33 & -0.04517 & 0.03929 & -1.15 \\
\hline ABOVEETR1 & 0.10652 & 0.00485 & $21.95 * * *$ & 0.08977 & 0.00935 & $9.60 * * *$ \\
\hline ABOVEETR $1 *$ INDEGREE & & & & 0.00029 & 0.00014 & $2.09 * *$ \\
\hline INDEGREE & 0.00004 & 0.00008 & 0.49 & -0.00010 & 0.00010 & -0.97 \\
\hline LARGEST & 0.06502 & 0.01915 & $3.40 * * *$ & 0.06556 & 0.01914 & $3.42 * * *$ \\
\hline SIZE & -0.00308 & 0.00139 & $-2.22 * *$ & -0.00309 & 0.00139 & $-2.23 * *$ \\
\hline LEVERAGE & -0.08546 & 0.00939 & $-9.10 * * *$ & -0.08542 & 0.00939 & $-9.10 * * *$ \\
\hline Group dummy & Include & & & Include & & \\
\hline Industry dummy & Include & & & Include & & \\
\hline Year dummy & Include & & & Include & & \\
\hline $\mathrm{N}$ & 3788 & & & 3788 & & \\
\hline F-value for the model & 18.76 & & & 18.60 & & \\
\hline (p-value) & $(<.0001)$ & & & $(<.0001)$ & & \\
\hline $\mathrm{R}^{2}$ & 0.2934 & & & 0.2942 & & \\
\hline
\end{tabular}

Panel C: Regression Results Using the Effective Tax Rate 2 and Indegree

PTAXROA $=\beta 0+\beta 1$ ETR $2+\beta 2($ ETR $2 *$ INDEGREE $)+\beta 3$ INDEGREE $+\beta 4$ LARGEST $+\beta 5$ SIZE $+\beta 6$ LEVERAGE $+\beta 7$ Group dummy $+\beta 8$ Industry dummy $+\beta 9$ Year dummy $+\varepsilon$

\begin{tabular}{|c|c|c|c|c|c|c|}
\hline Variable & Coefficient & $\begin{array}{c}\text { Standard } \\
\text { Error }\end{array}$ & t-statistic & Coefficient & $\begin{array}{c}\text { Standard } \\
\text { Error }\end{array}$ & t-statistic \\
\hline Intercept & -0.03897 & 0.04103 & -0.95 & -0.03582 & 0.04110 & -0.87 \\
\hline ETR2 & 0.10583 & 0.01006 & $10.52 * * *$ & 0.08415 & 0.01908 & 4.41 \\
\hline ETR2*INDEGREE & & & & 0.00038 & 0.00028 & 1.34 \\
\hline INDEGREE & 0.00009 & 0.00008 & 1.06 & 0.00002 & 0.00010 & 0.24 \\
\hline LARGEST & 0.07682 & 0.02006 & $3.83 * * *$ & 0.07809 & 0.02008 & 3.89 \\
\hline SIZE & -0.00151 & 0.00145 & -1.04 & -0.00151 & 0.00145 & -1.04 \\
\hline LEVERAGE & -0.11069 & 0.00974 & $-11.36 * * *$ & -0.11007 & 0.00975 & -11.29 \\
\hline Group dummy & Include & & & Include & & \\
\hline Industry dummy & Include & & & Include & & \\
\hline Year dummy & Include & & & Include & & \\
\hline $\mathrm{N}$ & 3788 & & & 3788 & & \\
\hline F-value for the model & 13.09 & & & 12.96 & & \\
\hline (p-value) & $(<.0001)$ & & & $(<.0001)$ & & \\
\hline $\mathrm{R}^{2}$ & 0.2247 & & & 0.2250 & & \\
\hline
\end{tabular}

Panel D: Regression Results Using the Effective Tax Rate Dummy 2 and Indegree

PTAXROA $=\beta 0+\beta 1$ ABOVEETR $2+\beta 2($ ABOVEETR $2 *$ INDEGREE $)+\beta 3$ INDEGREE + $\beta 4$ LARGEST $+\beta$ 5SIZE $+\beta 6$ LEVERAGE $+\beta 7$ Group dummy $+\beta 8$ Industry dummy $+\beta 9$ Year dummy $+\varepsilon$

\begin{tabular}{|c|c|c|c|c|c|c|}
\hline Variable & Coefficient & $\begin{array}{c}\text { Standard } \\
\text { Error }\end{array}$ & t-statistic & Coefficient & $\begin{array}{c}\text { Standard } \\
\text { Error }\end{array}$ & t-statistic \\
\hline Intercept & -0.04917 & 0.04048 & -1.21 & -0.04159 & 0.04053 & -1.03 \\
\hline ABOVEETR2 & 0.07490 & 0.00508 & $14.73 * * *$ & 0.05198 & 0.00964 & $5.39 * * *$ \\
\hline ABOVEETR2*INDEGREE & & & & 0.00040 & 0.00014 & $2.80 * *$ \\
\hline INDEGREE & 0.00009 & 0.00008 & 1.10 & -0.00011 & 0.00011 & -1.02 \\
\hline LARGEST & 0.07069 & 0.01979 & $3.57 * * *$ & 0.07180 & 0.01978 & $3.63 * * *$ \\
\hline SIZE & -0.00245 & 0.00144 & $-1.71 *$ & -0.00241 & 0.00144 & $-1.68 *$ \\
\hline LEVERAGE & -0.10751 & 0.00960 & $-11.20 * * *$ & -0.10606 & 0.00961 & $-11.04 * * *$ \\
\hline Group dummy & Include & & & Include & & \\
\hline Industry dummy & Include & & & Include & & \\
\hline Year dummy & Include & & & Include & & \\
\hline $\mathrm{N}$ & 3788 & & & 3788 & & \\
\hline F-value for the model & 14.72 & & & 14.66 & & \\
\hline (p-value) & $(<.0001)$ & & & $(<.0001)$ & & \\
\hline $\mathrm{R}^{2}$ & 0.2457 & & & 0.2473 & & \\
\hline
\end{tabular}


Table 8: Results of Multivariate Regression Analyses

\begin{tabular}{|c|c|c|c|c|c|c|}
\hline \multicolumn{7}{|c|}{ Panel A: Regression Results Using the Effective Tax Rate 1 and Nrm_Indegree } \\
\hline \multicolumn{7}{|c|}{$\begin{aligned} \text { PTAXROA }=\beta 0+ & \beta 1 \text { ETR } 1+\beta 2(E T R 1 * \text { Nrm_INDEGREE })+\beta 3 \text { Nrm_INDEGREE }+\beta 4 \text { LARGEST }+\beta 5 \text { SIZE } \\
& +\beta 6 \text { LEVERAGE }+\beta 7 \text { Group dummy }+\beta 8 \text { Industry dummy }+\beta 9 \text { Year dummy }+\varepsilon\end{aligned}$} \\
\hline Variable & Coefficient & Standard Error & t-statistic & Coefficient & Standard Error & t-statistic \\
\hline Intercept & -0.02838 & 0.03751 & -0.76 & -0.02918 & 0.03749 & -0.78 \\
\hline ETR1 & 0.17789 & 0.01565 & $11.37 * * *$ & 0.15739 & 0.01816 & $8.66^{* * *}$ \\
\hline $\begin{array}{l}\text { ETR } 1^{*} \\
\text { NRM_INDEGREE }\end{array}$ & & & & 0.00890 & 0.00401 & $2.22 * *$ \\
\hline NRM_INDEGREE & -0.00030 & 0.00057 & -0.52 & -0.00117 & 0.00069 & $-1.69 *$ \\
\hline LARGEST & 0.07739 & 0.01977 & $3.92 * * *$ & 0.07725 & 0.01975 & $3.91 * * *$ \\
\hline SIZE & -0.00163 & 0.00134 & -1.22 & -0.00157 & 0.00134 & -1.17 \\
\hline LEVERAGE & -0.11339 & 0.00959 & $-11.82 * * *$ & -0.11277 & 0.00959 & $-11.76 * * *$ \\
\hline Group dummy & Include & & & Include & & \\
\hline Industry dummy & Include & & & Include & & \\
\hline Year dummy & Include & & & Include & & \\
\hline $\mathrm{N}$ & 3788 & & & 3788 & & \\
\hline F-value for the model & 13.37 & & & 13.28 & & \\
\hline (p-value) & $(<.0001)$ & & & $(<.0001)$ & & \\
\hline $\mathrm{R}^{2}$ & 0.2283 & & & 0.2293 & & \\
\hline
\end{tabular}

Panel B: Regression Results Using the Effective Tax Rate Dummy 1 and Nrm_INDEGREE

PTAXROA $=\beta 0+\beta 1$ ABOVEETR $1+\beta 2($ ABOVEETR $1 *$ Nrm_INDEGREE) $+\beta 3$ Nrm_INDEGREE $+\beta 4$ LARGEST $+\beta$ SIZE $+\beta 6$ LEVERAGE $+\beta 7$ Group dummy $+\beta 8$ Industry dummy $+\beta 9$ Year dummy $+\varepsilon$

\begin{tabular}{lcccccc}
\hline \multicolumn{1}{c}{ Variable } & Coefficient & Standard Error & t-statistic & Coefficient & Standard Error & t-statistic \\
\hline Intercept & -0.03688 & 0.03589 & -1.03 & -0.03683 & 0.03589 & -1.03 \\
ABOVEETR1 & 0.10661 & 0.00485 & $21.97 * * *$ & 0.10580 & 0.00537 & 19.71 \\
ABOVEETR1* & & & & 0.00030 & 0.00085 & 0.36 \\
NRM_INDEGREE & & & -0.84 & -0.00062 & 0.00071 & -0.87 \\
NRM_INDEGREE & -0.00046 & 0.00055 & $3.40^{* * *}$ & 0.06441 & 0.01893 & $3.40^{* * *}$ \\
LARGEST & 0.06435 & 0.01892 & $-2.77^{* *}$ & -0.00356 & 0.00129 & $-2.76^{* *}$ \\
SIZE & -0.00356 & 0.00129 & $-9.11^{* * *}$ & -0.08467 & 0.00930 & $-9.10^{* * *}$ \\
LEVERAGE & -0.08474 & 0.00930 & & Include & & \\
Group dummy & Include & & & Include & & \\
Industry dummy & Include & & & Include & & \\
Year dummy & Include & & & 18.54 & & \\
N & 3788 & & & $(<.0001)$ & & \\
F-value for the model & 18.76 & & & & & \\
(p-value) & $(<.0001)$ & & & & & \\
$\mathrm{R}^{2}$ & 0.2934 & & & & & \\
\hline
\end{tabular}

Panel C: Regression Results Using the Effective Tax Rate 2 and Nrm_INDEGREE

PTAXROA $=\beta 0+\beta 1$ ETR $2+\beta 2($ ETR2 $*$ Nrm_INDEGREE $)+\beta 3$ Nrm_INDEGREE $+\beta 4$ LARGEST + $\beta 5$ SIZE

$+\beta 6$ LEVERAGE $+\beta 7$ Group dummy $+\beta 8$ Industry dummy $+\beta 9$ Year dummy $+\varepsilon$

\begin{tabular}{|c|c|c|c|c|c|c|}
\hline Variable & Coefficient & Standard Error & t-statistic & Coefficient & Standard Error & t-statistic \\
\hline Intercept & -0.01554 & 0.03759 & $\begin{array}{l}-0.41 \\
\end{array}$ & -0.01705 & 0.03758 & -0.45 \\
\hline ETR2 & 0.10564 & 0.01006 & $10.50^{* * *}$ & 0.08933 & 0.01233 & 7.25 \\
\hline $\begin{array}{l}\text { ETR2* } \\
\text { Nrm_INDEGREE }\end{array}$ & & & & 0.00724 & 0.00316 & $2.29 * *$ \\
\hline Nrm_INDEGREE & -0.00027 & 0.00057 & -0.47 & -0.00147 & 0.00077 & $-1.89 *$ \\
\hline LARGEST & 0.07391 & 0.01983 & $3.73 * * *$ & 0.07546 & 0.01983 & $3.81 * * *$ \\
\hline SIZE & -0.00226 & 0.00135 & $-1.68 *$ & -0.00217 & 0.00135 & -1.61 \\
\hline LEVERAGE & -0.10924 & 0.00965 & $-11.32 * * *$ & -0.10829 & 0.00966 & $-11.21 * * *$ \\
\hline Group dummy & Include & & & Include & & \\
\hline Industry dummy & Include & & & Include & & \\
\hline Year dummy & Include & & & Include & & \\
\hline $\mathrm{N}$ & 3788 & & & 3788 & & \\
\hline F-value for the model & 13.08 & & & 13.00 & & \\
\hline (p-value) & $(<.0001)$ & & & $(<.0001)$ & & \\
\hline $\mathrm{R}^{2}$ & 0.2245 & & & 0.2256 & & \\
\hline
\end{tabular}


Table 8 cont.

\begin{tabular}{|c|c|c|c|c|c|c|}
\hline \multicolumn{7}{|c|}{ Panel D: Regression Results Using the Effective Tax Rate Dummy 2 and Nrm_INDEGREE } \\
\hline \multicolumn{7}{|c|}{$\begin{aligned} \text { PTAXROA }= & \beta 0+\beta 1 \text { ABOVEETR } 2+\beta 2(\text { ABOVEETR } 2 * \text { Nrm_INDEGREE })+\beta 3 \text { Nrm_INDEGREE }+\beta 4 \text { LARGEST } \\
& +\beta 5 \text { SIZE }+\beta 6 \text { LEVERAGE }+\beta \text { Group dummy }+\beta 8 \text { Industry dummy }+\beta 9 \text { Year dummy }+\varepsilon\end{aligned}$} \\
\hline Variable & Coefficient & Standard Error & t-statistic & Coefficient & Standard Error & t-statistic \\
\hline Intercept & -0.02620 & 0.03708 & -0.71 & -0.02637 & 0.03709 & -0.71 \\
\hline ABOVEETR2 & 0.07481 & 0.00508 & $14.71 * * *$ & 0.07345 & 0.00563 & $13.06 * * *$ \\
\hline $\begin{array}{l}\text { ABOVEETR } 2 * \\
\text { NRM_INDEGREE }\end{array}$ & & & & 0.00050 & 0.00089 & 0.56 \\
\hline NRM_INDEGREE & -0.00021 & 0.00056 & -0.37 & -0.00049 & 0.00075 & -0.65 \\
\hline LARGEST & 0.06761 & 0.01957 & $3.45 * * *$ & 0.06769 & 0.01957 & $3.46^{* * *}$ \\
\hline SIZE & -0.00319 & 0.00133 & $-2.39 * *$ & -0.00317 & 0.00133 & $-2.38 * *$ \\
\hline LEVERAGE & -0.10604 & 0.00951 & $-11.15 * * *$ & -0.10584 & 0.00952 & $-11.12 * * *$ \\
\hline Group dummy & Include & & & Include & & \\
\hline Industry dummy & Include & & & Include & & \\
\hline Year dummy & Include & & & Include & & \\
\hline $\mathrm{N}$ & 3788 & & & 3788 & & \\
\hline F-value for the model & 14.70 & & & 14.52 & & \\
\hline (p-value) & $(<.0001)$ & & & $(<.0001)$ & & \\
\hline $\mathrm{R}^{2}$ & 0.2455 & & & 0.2455 & & \\
\hline
\end{tabular}

\section{CONCLUSION}

In this study, we examined how income shifting performs among affiliates in a business group to maximize the benefits of the entire business group in terms of minimizing the tax burden, with a particular focus on the direction of income shifting between affiliates within the business group. The results of the analysis demonstrated that performing income shifting occurs frequently in firms that invest more shares in other affiliates within the business group. That is, giving income shifting is common among affiliates with high outdegree centrality. Firms that are invested from affiliates within their business group tend to be recipients of income shifting. That is, income is shifted to affiliates with high indegree centrality. Thus, the ownership structure, which represents the relationships between affiliates, affects the decision-making of the controlling shareholders about income shifting for the purpose of maximizing the benefits of the entire business group.

The contribution of this study is as follows. First, previous studies revealed the private interests of the controlling shareholders as a decisive factor in the direction of income shifting through internal transactions. In this study, we examined how the relationships among affiliated firms affect income shifting after controlling for the private interests of the controlling shareholders. In addition, we use centrality variables of social network analysis techniques to analyze the ownership structure of Korean conglomerates. The limitation of this study is that the variables such as OUTDEGREE and INDEGREE is just the direct equity rates, apart from the indirect equity rates. While the direct share ratio between affiliated firms may have a direct influence on decision-making for each affiliate, since Korean business groups have formed pyramidal ownership structure, and cross-shareholdings ownership, indirect control rights through other affiliated firms in complicated ownership structures would be considered.

\section{AUTHOR INFORMATION}

Kyung Jin Park, Ph.D., Myongji University, Department of Business Administration, 50-3 Namgajadong, Seodaemungu, Seoul, 120-728, Korea. E-mail: chichikj@ mju.ac.kr

Joohyun Lim, Yonsei University, Ph.D. Candidate, Department of Business Administration, 134 Shinchon-dong, Seodaemoon-gu, Seoul 120-749, Korea. E-mail: joohyun_lim@yonsei.ac.kr (Corresponding author)

Ki Young Kim, Ph.D., Myongji University, Department of Business Administration, 50-3 Namgajadong, Seodaemungu, Seoul, 120-728, Korea. E-mail: kykim@mju.ac.kr 


\section{REFERENCES}

1. Bertrand, M., Mehta, P., \& Mullainathan, S. (2002). Ferreting out tunneling: An application to Indian business groups. Quarterly Journal of Economics, 118(1), 121-148.

2. Cheung, Y.-L., Raghavendra Rau, P., \& Stouraitis, A. (2006). Tunneling, propping and expropriation: evidence from connected party transactions in Hong Kong. Journal of Financial Economics, 82(2), 343386.

3. Collins J. H., \& Shackelford, D. A. (1998). Global organization and taxes: An analysis of the dividend, interest, royalty, and management fee payments between U.S. multinationals' foreign affiliates. Journal of Accounting and Economics, 24(2), 151-173.

4. Harris, D. G, Morck, R., Slemrod, J., \& Yeung, B. (1993). Income shifting in U. S. multinational corporations. Studies in International Taxation.

5. Jacob, J. (1996). Taxes and transfer pricing: Income shifting and the volume of intrafirm transfers. Journal of Accounting Research, 34(Autumn), 301-312.

6. Friedman, E., Johnson, S., \& Mitton, T. (2003). Propping and tunneling. Journal of Comparative Economics, 31(4), 732-750.

7. Johnson, S., La Porta, R., Lopez-de-Silanes, F., \& Shleifer, A. (2002). Tunneling. American Economic Review, 90, 22-27.

8. Gordon, E. A., Henry, E., \& Palia, D. (2004). Related party transactions and corporate governance and firm value. Advances in Financial Economics, 9(b), 1-27.

9. Grubert, H., \& Mutti, J. (1991). Taxes, tariffs, and transfer pricing in multinational corporate decision making. The Review of Economics and Statistics, May.

10. Klassen, K, Lang, M., \& Wolfson, M. (1993). Geographic income shifting by multinational corporations in response to tax rate changes. Journal of Accounting Research, 31,140-173.

11. Ko, J. K. (2000). Transfer pricing and tax minimization: Income shifting by Korea multinational companies. Korean Accounting Review, 25(2), 51-77.

12. Kooyul, J., Kim, B., \& Kim, B. (2009). Tax motivatied income shifting and Korean Business Group (Chaebol). Journal of Business Finance \& Accounting, 36(5 \& 6), 552-586.

13. Mills, L., \& Newberry, K. (2004). Do worldwide tax incentives affect the income reporting and debt

14. policy of foreign-controlled U.S. corporations? National Tax Journal, 57, 89-107.

15. Rego, S. O. (1999). Multinational income shifting and the endogenous relationship between firm profitability and effective tax rates. (Working Paper). University of Iowa.

16. Rho, J. H. (1997). Tax incentives for income shifting through transfer pricing. Korean Accounting Review, 22(4), 221-251.

17. Riyanto, Y. E., \& Toolsema, L. A. (2008). Tunneling and propping: A justification for pyramidal ownership. Journal of Banking and Finance, 32(10), 2178-2187.

18. Choi, C.-G. (2009). An analysis of the equity holding structures of Korean Business Groups. Korea Economic Research Institute.

19. Park, J. K., \& Kim, H. (2007). Income shifting of conglomerates and tax burden. Journal of Business Research, 22(1), 175-201. 


\section{APPENDIX 1}

A. The business group is defined as follows in the Law of Monopoly Regulations and Fair Trade. The business group is a group of firms that the identical person or corporation controls the contents of the business in actual. The range of the business group, that is, whether it is an affiliated firm or not is judged with the criteria of control power or equity rates. Summary of the criteria for judging the affiliated firms is as follows:

a. Terms of Equity Rates: The firm of which the same party or the party related to the same party possesses more than $30 \%$ and is the biggest shareholder.

b. Terms of Control Power (Influence):

- The same can appoint more than 50/100 of officials

- The same party exercises the predominant influence on major decision makings or enforcement, such as organization shift and new business investment of the related firm.

- The same party serving as an official in the controlling company and the related company in the additional post and interchange of Personnel.

- By exceeding the common rage, the company considered as an economic identity with the same party and the party related to the same party on the common sense, such as finance, assets, goods, services transaction, debt assurance, warrant and indicating activities on business that can be admitted as its affiliated firm.

B. The party related to controlling shareholder (the same party) on Law of Monopoly Regulations and Fair Trade is shown as following:

a. Spouse, cognates within second cousin, and relatives within first cousin.

b. Non-profit corporation or organization that the same party or the party related to the same party exercises a predominant influence on the composition of its official or business operation, or Nonprofit corporation or organization with the unique founder or that the same party or the party related to the same party becomes the biggest shareholder by totaling the same party or the party related to the same party.

c. Affiliated Firms

d. The same party of the employee of non-profit corporation, organization, and affiliated firms that are under the same party's control. 